\title{
Efficiency of pseudomonas aeruginosa and Escherichia coli to treatment of effluent petroleum wastewater from AI-Nasiriya refinery - Iraq
}

\author{
Ihsan Flayyih Hasan AI-Jawhari ${ }^{1 *}$,Noor Jabar Mhail ${ }^{2}$, Saher Abed AI-RuthaAli ${ }^{2}$ \\ ${ }^{I}$ Department of Environment and Pollution, Marshes Research Centre, Thi-Qar University,Iraq \\ ${ }^{2}$ Department of Chemistry, College of Science, Thi-Qar University,Iraq \\ *Corresponding author_E-mail:dr.ihsan_2012@yahoo.com
}

Copyright () 2015 Ihsan Flayyih Hasan AI-Jawhari et al. This is an open access article distributed under the Creative Commons Attribution License, which permits unrestricted use, distribution, and reproduction in any medium, provided the original work is properly cited.

\begin{abstract}
Fourbacteria isolated from the soil contaminated with petroleum hydrocarbon and wastewaters from the refinerylocated in the south part of AI-Nasiriya city in Iraq,by using dilution method.The results showed that Pseudomonas aeruginosawas more dominant with $100 \%$ in soil and wastewaters in inside of refinery,and $93 \%, 95 \%$ in soil and wastewaters in outside the refinery respectively.The results showed that the second dominant of bacteria was Esherchia coil with $92 \%, 98 \%$ in soil and wastewaters in inside the refinery,and $83 \%, 88 \%$ in soil and wastewaters in outside of refinery.The remaining two species of bacteria isolated with a very low frequency,these bacteria were Bacillus subtilis and Klebsiella sp., B.subtilis was obtained with $10 \%, 8 \%$ in soil and wastewaters in inside the refinery,and 10\%,3\% in soil and wastewaters in outside of refinery .In the same time that Klebsiella sp. Was obtained with $10 \%$ in soil and wastewaters in inside the refinery,and $8 \%, 3 \%$ in soil and wastewaters in outside the refinery.The results showed that mixed two bacteria (high frequency)were more efficient to decrease Biological Oxygen Demande(BOD)with 59\% in $\mathrm{pH} 4,0.5 \mathrm{gm} / \mathrm{I}$ salt $(\mathrm{NaCI})$ concentration.Chemical Oxygen Demande (COD) was decreased to $75 \%$. The results showed that the Total Acidity(TA) in wastewater were increased to $82 \% \mathrm{mg} / \mathrm{I}$ in $40 \mathrm{c}^{\circ}, \mathrm{pH} 8$ and $2.0 \mathrm{gm} / \mathrm{I} \mathrm{NaCI}$, and Total Suspended Solid (TSS) was decreased to $50 \mathrm{mg} / \mathrm{I}$ in $40 \mathrm{c}^{\circ}, \mathrm{pH} 8,2.0 \mathrm{gm} / \mathrm{I} \mathrm{NaCI}$. The results showed that the Total Petroleum Hydrocarbon (TPH) was removal with $99.99 \%$, and in the same time the numbers of mixed bacteria were increased to $5 \times 10^{8}$ after incubation $48 \mathrm{~h}$ in $40 \mathrm{c}^{\circ}$.
\end{abstract}

Keywords: Bacteria; Refinery; Soil; Total Acidity; Wastewater

\section{Introduction}

Large amount of water are used for industrial activities and consequently, significant volumes of wastewater are generated. Based on the type of industry, various levels of pollutants are deliberately released and discharged into the environment directly. A mong these industries that discharge their effluents into the aquatic environments are the petroleum oil refineries. As not all refineries have the same processes, the effluents that are produced will have different chemical compositions depending on the type of treatment they received [1], [2]. Wastewater released by oil refineries contain large amount of toxic derivatives such as oil and grease, Phenols, Sulphides, Cyanides, Suspended solids, nitrogen compounds as well as heavy metals such as iron, nickel, copper, selenium, zink, molybdenum, etc [3]. Due to the ineffectiveness of purification systems, wastewater from the refineries may become seriously dangerous, leading to the accumulation of toxic products in the receiving water bodies with potentially serious consequences on the ecosystem [4]. Thus the discharge of these effluents containing persistant chemicals into a receiving water body may result in the long-term effects to aquatic biota [5].

The toxicity of oil refinery effluents to aquatic organisms have being reported in many literatures. Toxicity of petroleum refinery depends on a number of factors, which include quantity, volume and variability of discharge. The different components of the effluents may have varying effects and toxicity [6].[7]showed that the petroleum did not persist for 
long periods in the most soils even when relatively large quantities of petroleum have spilled, This is probably due to large part to the initial degradation by the action of sun light followed by microbial attack when the oil sink. Fungi and other microorganisms have the ability to degrade several pollutants, including crude oil in the aquatic ecosystem and utilize them as a nutrient source [8].They They may also metabolize such as pollutants to substrates with low harmful effect on the environment [9], [10], [11].The efficiency of bacteria isolated from soil and wastewater to treatment of effluent petroleum wastewater from AI-Nasiriya refinery has not been investigated, and the present study investigated the quality of the refinery effluent discharge.

\section{Materials and methods}

\subsection{Characterization of petroleum oil refinery wastewaters}

Non-treated Petroleum oil refinery wastewater were collected from inside and outside refinery by using 5 litres polyethylene containers. The containers were rinsed several times with the effluent sample at the point of collection.The sample were taken to the laboratory within $1 \mathrm{~h}$ of collection,BOD ,COD ,TSS ,TPH ,Total acidity ,Cations $(\mathrm{Cd}, \mathrm{Pb}, \mathrm{Ni}, \mathrm{Zn}, \mathrm{Fe}$ and $\mathrm{Cu}$ )in wastewater samples were determined according to standard methods [12].

\subsection{Bacteria strains and cultures conditions}

The bacteria strains used in this study was isolated from soil and wastewater samples collected from effluent discharged to refinery in AI-Nasiriya city.One media was applied to isolated bacteria from soil and wastewater by using Nutrient agar(NA),the media was supplemented with $30 \mu \mathrm{g} / \mathrm{I}$ Nystatin to suppress fungi growth. Plates and media were incubated at $37 \mathrm{c}^{\mathrm{o}}$ in the dark. Stock cultures were maintained on Nutrient agar,subculture periodically and stored at 4 $\mathrm{c}^{\mathrm{o}}$.Bacterial specimens were examined under light microscope after preparations and identified using morphological characters , gram stain, biochemical tests and API20E[13] and taxonomical keys provided in the bacteriological keys $[14],[15]$.

\subsection{Determination of biodegradation potential bacteria}

To determine the biodegradation potential of oil degrading isolate bacteria. Add $500 \mathrm{mI}$ of wastewater from AI-Nasiriya refinery after sterilized by autoclave to Erlenmeyer flasks and incubated with $2 \mathrm{mI}$ from axenic and mixed cultures of bacteria colony .All flasks were covered with non-cotton wool absorbent and incubated at $\left(10,20,30,40 \mathrm{c}^{\mathrm{o}}\right) \mathrm{with} \mathrm{pH}($ $2,4,6,8)$ by using $\mathrm{HCL}$ or $\mathrm{NaOH}$ and add $(0.0,0.5,1.0,2.0 \mathrm{gm} / \mathrm{I}) \mathrm{NaCI}$. Control flasks were left without microbes and these experiments were duplicate. The flasks were shaken manually at regular intervals to allow adequate mixing and homogeneity of the contents. $1 \mathrm{mI}$ of liquid culture was transfer to test tubes containing $9 \mathrm{mI}$ distilled water and $1 \%$ pepton and make serial dilution . $1 \mathrm{mI}$ from diluted $10^{7}$ was cultured by using plate count, and determined microbial numbers after incubation $24 \mathrm{~h}[16]$. These expermint were duplicated.

A nalysis of the bacteria biodegradation activity was made using a computerized capillary gas chromatography with flame ionized GC- FID ( Backard438 A ) and flame ionization detector set at $325 \mathrm{c}^{\mathrm{o}}$. The carrier gas was Helium at flow rate of $30 \mathrm{mI} / \mathrm{min}$. The column length $3 \mathrm{~m}$, internal diameter $1 / 8 \mathrm{~mm}$. The temperature was programmed to increase from 100 to $300 c^{0}$ at $10 c^{\circ} /$ min. Individual compounds present in the fractions were determined by matching the retention time with authentic standards.

\subsection{Statistical analysis}

The present study conducted on Anova (analysis of variance) which was performed on all the treatments and done using the SPSS (version10.0) package to determine whether or not, a significance difference.

\section{Results and discussion}

The results of the chemical characterization of the oil refinery wastewater sample are shown in Table 1 . The wastewater sample have elevated levels of organic compounds as indicate by the concentrations of BOD,COD, and TPH.

Table 1: Showed a reduction in the values of $\mathrm{Zn}, \mathrm{Cd}, \mathrm{Pb}, \mathrm{Ni}, \mathrm{Fe}$ in outside the refinery but $\mathrm{Cu}$ was increased.

Table 2 Showed the bacterial strain isolated from soil and wastewater from AI-Nasiriya refinery. P.aeruginosa was more dominant with $100 \%$ in soil and wastewater in inside the refinery, and 93\%, $95 \%$ in soil and wastewater in outside the refinery. The results showed that the second dominance of bacteria was Escherchia coli with $92 \%, 98 \%$ in soil and wastewater in inside the refinery, and $83 \%, 88 \%$ in soil and wastewater in outside of refinery. The remaining two species of bacteria isolated with a very low frequency, these bacteria were Bacillus subtilis and Klebsiellasp. ,B.subtilis was obtained with $10 \%, 8 \%$ in soil and wastewater in inside the refinery, and $10 \%, 3 \%$ in soil and wastewater in 
outside of refinery. In the same time that Klebsiella sp. was obtained with $10 \%$ in soil and wastewater in inside the refinery, and $8 \%, 3 \%$ in soil and wastewater in outside the refinery.

These results were similar to the findings of [17] which showed that increased in the bacterial population when presence of oil in the soil.

Table 1: Chemical characterization of the oil refinery wastewater.

\begin{tabular}{lll}
\hline Element & Inside Refinery & Outside Refinery \\
\hline $\mathrm{Zn}$ & $0.885^{*}$ & 0.460 \\
$\mathrm{Cd}$ & 0.137 & 0.083 \\
$\mathrm{~Pb}$ & 0.121 & 0.093 \\
$\mathrm{Ni}$ & 0.283 & 0.062 \\
$\mathrm{Fe}$ & 2.299 & 1.160 \\
$\mathrm{Cu}$ & 0.128 & 0.164 \\
\hline$* \mathrm{PPM}$ & &
\end{tabular}

Table 2: Total numbers of bacteria isolated from soil and wastewater in AI- Nasiriya refinery.

\begin{tabular}{|c|c|c|c|c|c|c|c|c|}
\hline \multirow{2}{*}{ Isolated bacteria } & \multicolumn{4}{|c|}{ Inside refinery } & \multicolumn{4}{|c|}{ Outside refinery } \\
\hline & Soil & $\%$ & Water & $\%$ & Soil & $\%$ & Water & $\%$ \\
\hline P.aeruginosa & $4 \times 10^{8}$ & 100 & $4 \times 10^{8}$ & 100 & $4 \times 10^{8}$ & 93 & $4 \times 10^{8}$ & 95 \\
\hline E.coli & $4 \times 10^{8}$ & 92 & $4 \times 10^{8}$ & 98 & $4 \times 10^{8}$ & 83 & $4 \times 10^{8}$ & 88 \\
\hline B.subtilis & $1 \times 10^{7}$ & 10 & $1 \times 10^{7}$ & 8.0 & $1 \times 10^{7}$ & 10 & $1 \times 10^{7}$ & 3.0 \\
\hline Klebsiella sp. & $1 \times 10^{7}$ & 10 & $1 \times 10^{7}$ & 10 & $1 \times 10^{7}$ & 8.0 & $1 \times 10^{7}$ & 3.0 \\
\hline
\end{tabular}

Similar results reports have indicate the increase of microbial population in the presence of oil contaminated soil [18] in their study about the effect of oil spill on the composition of microbes in a soil. The hydrocarbons may inhibited or caused by a death of certain microorganisms. On the other hand, there will also be increasing in numbers of certain microorganisms especially those capable of depending the hydrocarbons [19].

In the present study the total acidity was increased day after day in wastewater treatment with bacterial colony Table $3,4,5$. Highly values of total acidity was recorded in wastewater treatment with mixed bacteria, the total acidity reached to $82 \mathrm{mg} / \mathrm{I}$ in two day with $40 \mathrm{c}^{\circ}$ and $2.0 \mathrm{gm} \mathrm{NaCI}$, and in the same time the statistical methods observed nonsignificant differences with temperature. The increase of total acidity in wastewater treatment with bacteria refer to chemical changes of the hydrocarbon substrates and must have been precipitated by microbial enzymes [20].These results were similar to the findings of [21] which showed to increased the amount of acidity by using mixed of two strain of bacteria and these bacteria produced acidity to $75 \mathrm{mg} / \mathrm{I}$ when compared with $60 \mathrm{mg} / \mathrm{I}$ produced by using protozoa. Hydrogen ion concentration is a major variable govering the activity and composition of bacteria. Microbial degradation of hydrocarbon often leads to production of organic acids and other metabolic products [22].

Table 3: Values of Total Acidity in wastewater treatment with E.coli in different temperature, $\mathrm{pH}$.and Salt Concentration (NaCI).

\begin{tabular}{|c|c|c|c|}
\hline Temperature $\left(\mathrm{c}^{\mathrm{o}}\right)$ & $\mathrm{pH}$ & Salt concentrations (gm) & Total acidity ( $\mathrm{mg} / \mathrm{I})$ \\
\hline 10 & 2 & 0.0 & $36 *$ \\
\hline 20 & 4 & 0.5 & 42 \\
\hline 30 & 6 & 1.0 & 57 \\
\hline 40 & 8 & 2.0 & 61 \\
\hline Control & - & - & 34 \\
\hline
\end{tabular}

* Non-significant,(-): No record.

Table 4:Values of Total Acidity in wastewater treatment with P.aeruginosa in different temperature, $\mathrm{pH}$.and Salt Concentration (NaCI).

\begin{tabular}{|c|c|c|c|}
\hline Temperature $\left(\mathrm{c}^{\mathrm{O}}\right)$ & $\mathrm{pH}$ & Salt concentrations (gm.) & Total acidity (mg / I) \\
\hline 10 & 2 & 0.0 & $37 *$ \\
\hline 20 & 4 & 0.5 & 48 \\
\hline 30 & 6 & 1.0 & 64 \\
\hline 40 & 8 & 2.0 & 78 \\
\hline Control & - & - & 34 \\
\hline
\end{tabular}

(-): No record. * Non-significant

Table 5:Values of Total Acidity in wastewater treatment with mixed E.coli and P.aeruginosa in different temperature, pH.and Salt Concentration (NaCI).

\begin{tabular}{|c|c|c|c|}
\hline Temperature $\left(\mathrm{c}^{\mathrm{O}}\right)$ & $\mathrm{pH}$ & Salt concentrations (gm) & Total acidity ( mg / I ) \\
\hline 10 & 2 & 0.0 & $38 *$ \\
\hline 20 & 4 & 0.5 & 53 \\
\hline 30 & 6 & 1.0 & 69 \\
\hline 40 & 8 & 2.0 & 82 \\
\hline Control & - & - & - \\
\hline
\end{tabular}

\footnotetext{
* Non-significant,(-): No record.
} 
Table.6 showed decreased of BOD from $500 \mathrm{mg} / \mathrm{I}$ in control to $320 \mathrm{mg} / \mathrm{I}$ with P.aeruginosa , $390 \mathrm{mg} / \mathrm{I}$ with E.coli and $202 \mathrm{mg} / \mathrm{I}$ with mixed of two these bacteria , because the bacteria depend on dissolved oxygen in water to consumed organic compounds as asole of carbon and energy [23] , and increases of growth of microorganisms produced reduction of dissolved oxygen during oxidation process of dissolved hydrocarbons, The most complete degradation of the mainly of organic materials was occurred under aerobic conditions. The initial intracellular attack of organic materials was an oxidative process and oxygen consumption [24].

These results were similar to findings of [21], and the statistical methods obtained no significance differences between the treatments of bacteria.

Table 6:Values of Biological Oxygen Demandein wastewater treatment with different bacteria.

\begin{tabular}{lllll}
\hline Species of bacteria & $\mathrm{pH}$ & Salt concentration $(\mathrm{gm})$ & Values of BOD $(\mathrm{mg} / \mathrm{I})$ & Removal \% \\
\hline P.aeruginosa & 4 & 0.5 & $320^{*}$ & 36 \\
E.coli & 4 & 0.5 & 390 & 22 \\
Mixed two bacteria & 4 & 0.5 & 202 & 59 \\
Control & 4 & 0.5 & 500 & - \\
\hline
\end{tabular}

* Non significant, (-): No record.

Figure 1 Showed that the values of Chemical Oxygen Demande (COD) were decreased in wastewater treatment and the highest decreases were recorded with mixed bacteria in $40 \mathrm{c}^{\mathrm{o}}, \mathrm{pH} 8,2.0 \mathrm{gm} / \mathrm{I}$ Nacl and the removal percentage reached to $75 \%$ after $48 \mathrm{~h}$ when compared with control, this result due to the complete of chemical oxidation to all organic chemical compounds and the values of (COD) were higher than (BOD).

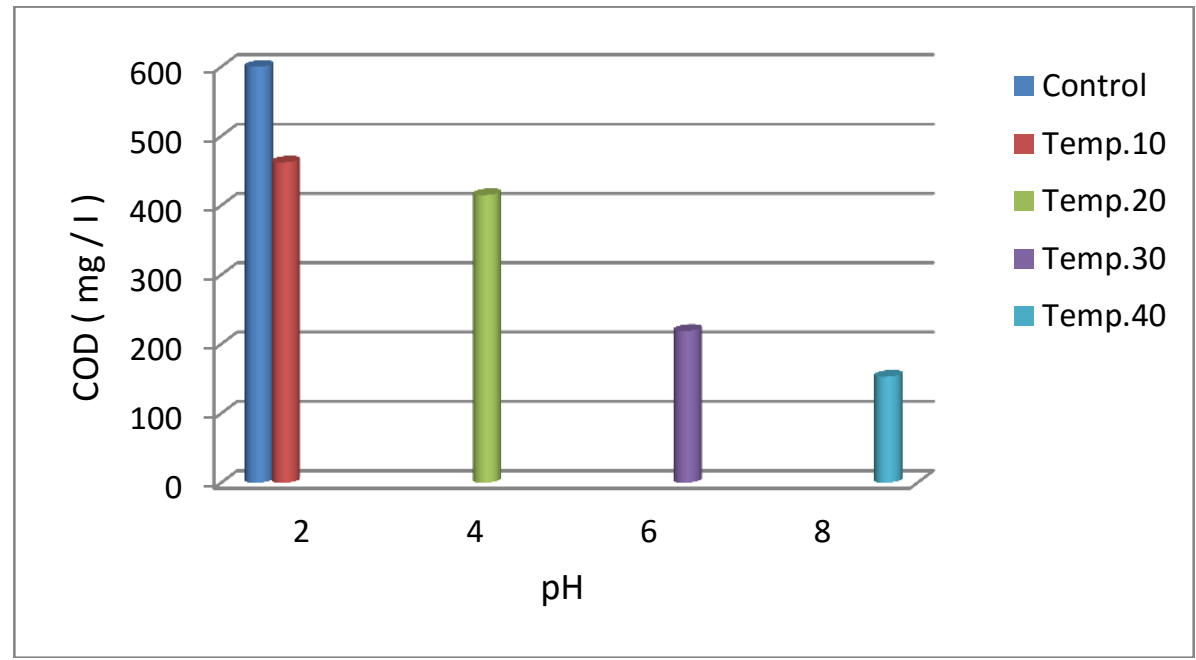

Fig. 1:Valuesof Chemical Oxygen Demandein wastewater treatment with mixed P.aeruginosa and E.coli in different temperature, pH.and 0.0, 0.5, $1.0,2.0 \mathrm{gm} / \mathrm{I}$ Salt Concentration NaCI.

These results were similar to the findings of [21] which showed to efficiency of mixed bacteria to decreased COD values.

These results were similar to the findings of [24] which showed that the pH were the effect on reduction of (COD), PAHS and TPH and the reduction increased with increasing $\mathrm{pH}$ value and the optimum amount of $\mathrm{pH}$ for reaching to complete mineralization was 7.5.

[24] Refer that temperature had a significant role in biodegradation of hydrocarbons with direct effecting on the chemistry of the pollutants, and effecting the diversity of the microbial flora. Temperature also effected on the solubility of hydrocarbons and the activity of the bio- enzyme. The biodegradation constants of removal (COD), PAHS and TPH reduction mainly reduced with decreasing temperature. The highest biodegradation rates that happened in the range 15$20 \mathrm{c}^{\mathrm{o}}$ in marine environment.At $20 \mathrm{c}^{\mathrm{o}}$ temperature the viscosity of the oil decreased , the volatility of the low molecular weight hydrocarbons were increased, bio- enzymatic oxidation were increased, and the accelerating the onset of biodegradation.

In the same time [24] found that (COD ), PAHS and TPH reduction was increased by an increase in the reaction's duration from 1 day to 10 days, and the percentage removal of ( COD ) reached to $100 \%$ in 10 days with the initial concentration of $440 \mathrm{mg}$ MI-1. Fig 2,3,4,5.Show decreased of Total Suspended Solid (TSS) in wastewater treatment with axenic and mixed culture of bacteria, the highest decreased were recorded with mixed bacteria in $40 \mathrm{c}^{\circ}, \mathrm{pH} 8,2.0$ $\mathrm{gm} / \mathrm{I} \mathrm{NaCI}$, and the value reached to $50 \mathrm{mg} / \mathrm{I}$ as well as the removal percentage reached to $88 \%$, but the percentage reached to $76 \%$, 56\% with alone culture of P.aruginosa and E.coli respectively after incubation $48 \mathrm{~h}$ when compared with control. 


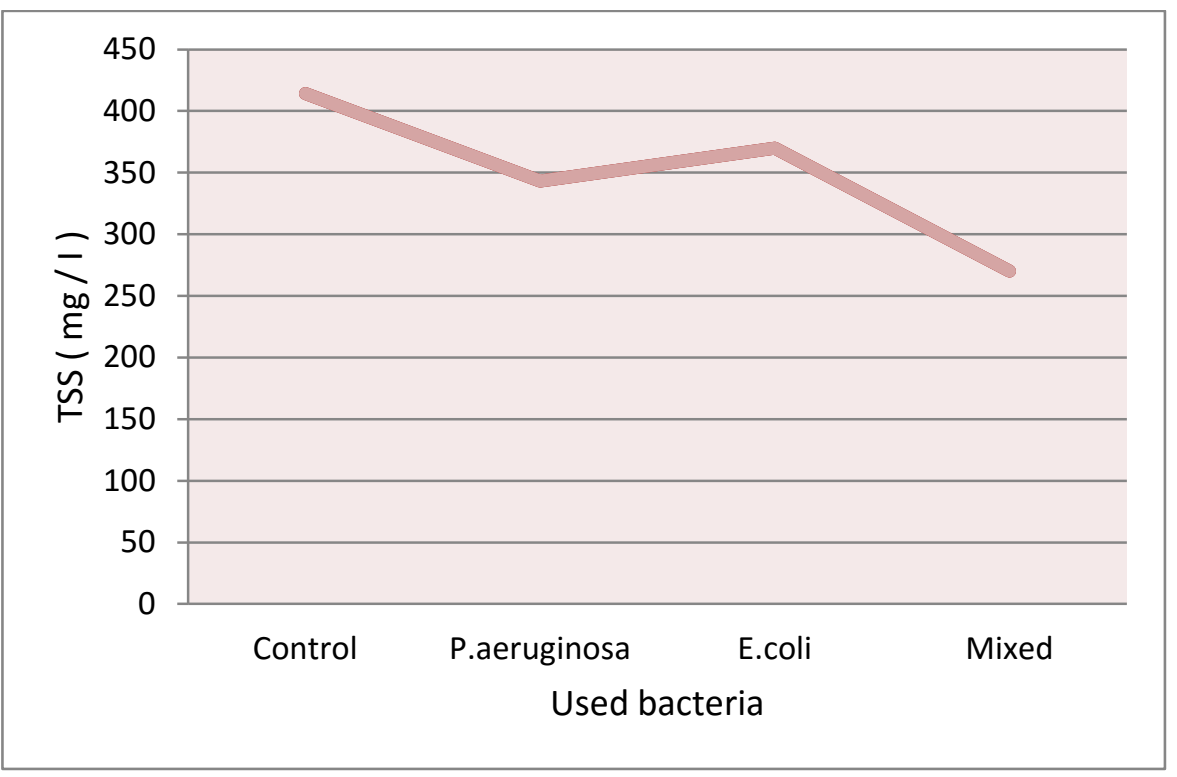

Fig. 2: Values of Total Suspended Solids (TSS) in wastewater treatment with in $10 \mathrm{C}^{\mathrm{o}}$, pH 2 and $0.0 \mathrm{gm} / \mathrm{I} \mathrm{NaCI}$.

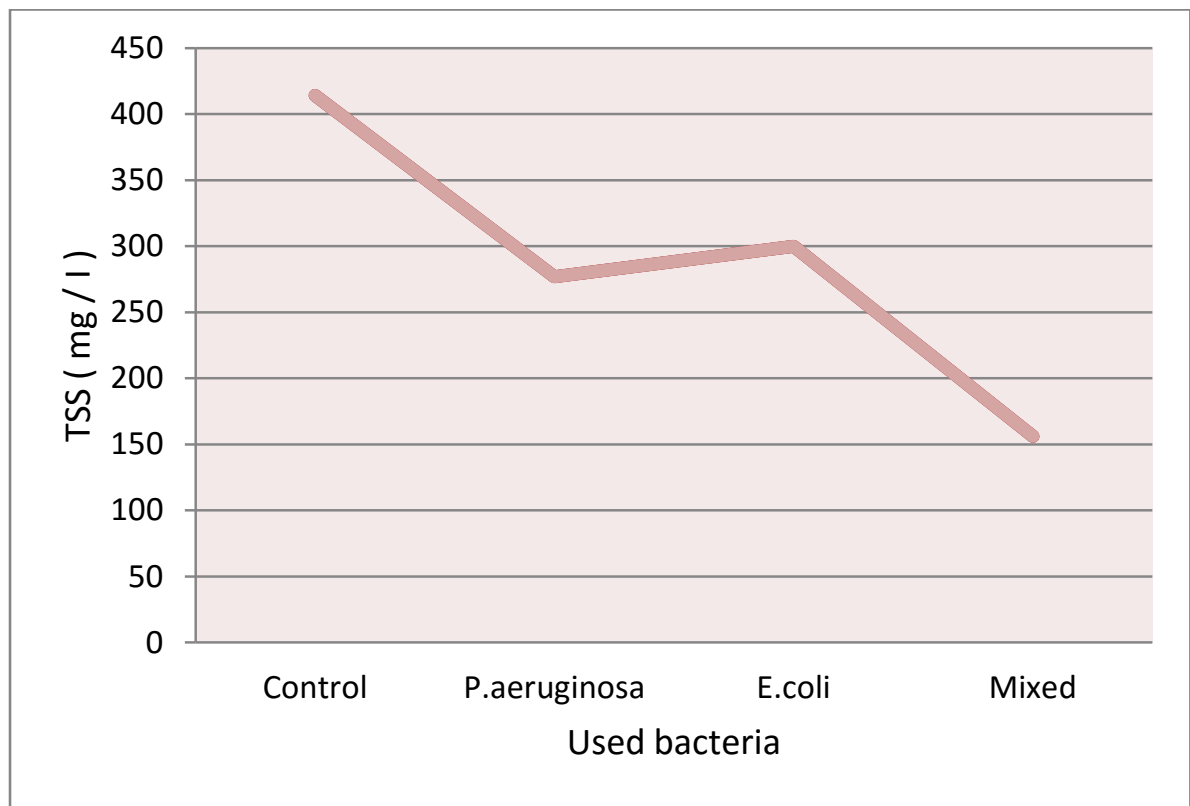

Fig .3: Values of Total Suspended Solids(TSS) in wastewater treatment with in $20 \mathrm{C}^{\mathrm{o}}$, pH 4 and $0.5 \mathrm{gm} / \mathrm{I}$ NaCI.

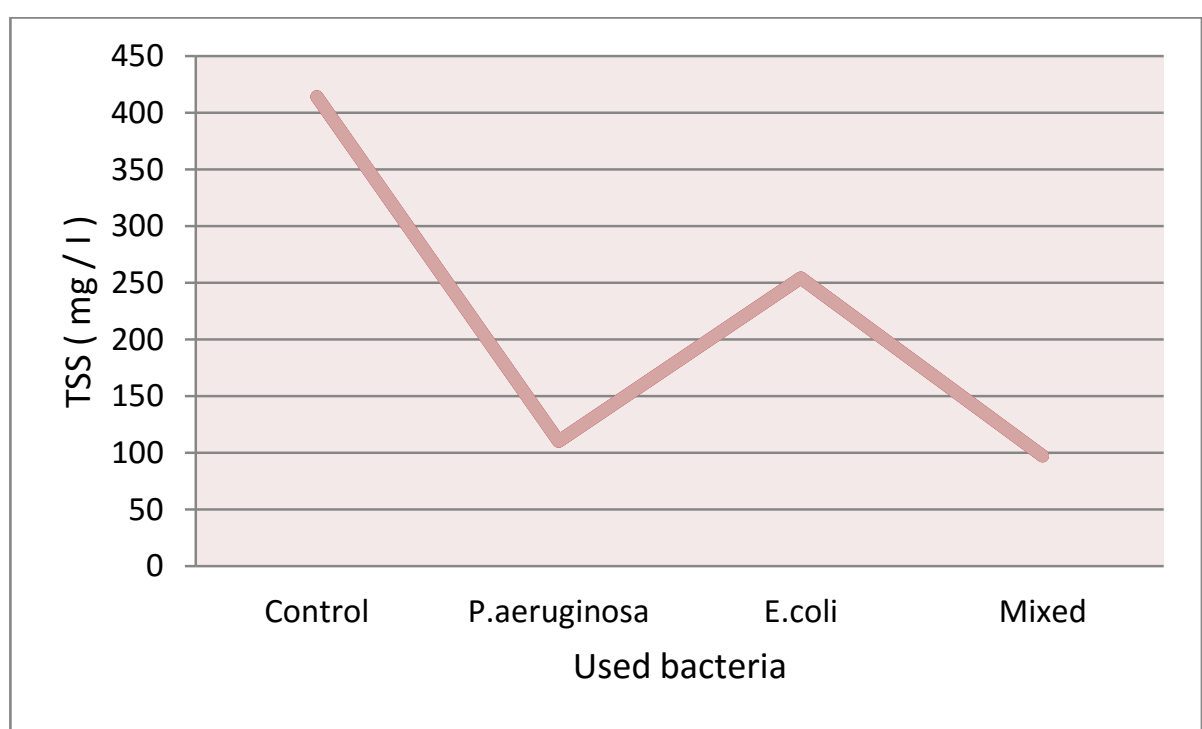

Fig .4: Values of Total Suspended Solid (TSS) in wastewater treatment with bacteria in $30 \mathrm{C}^{\circ}$, pH 6 and $1.0 \mathrm{gm} / \mathrm{I}$ NaCI. 


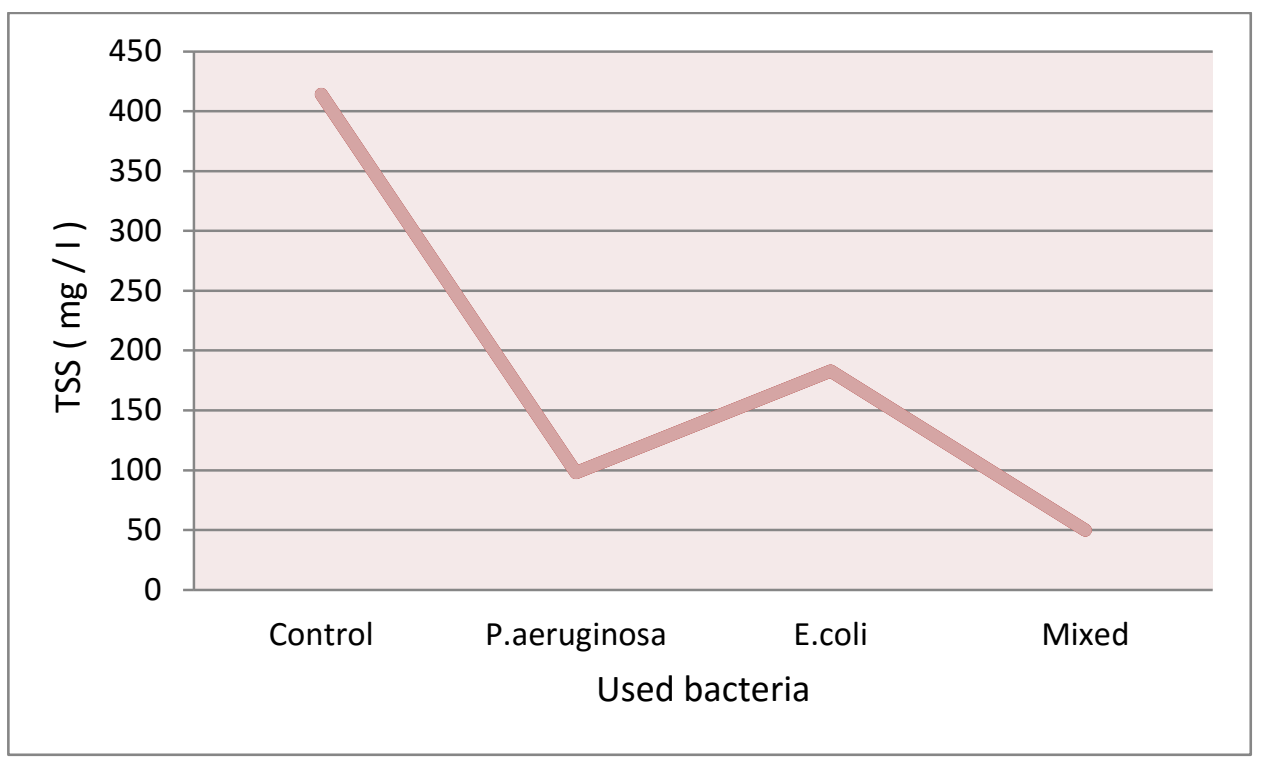

Fig .5: Values of Total Suspended Solids(TSS) in wastewater treatment with in $40 \mathrm{C}^{\mathrm{o}}, \mathrm{pH} 8$ and $2.0 \mathrm{gm} / \mathrm{I} \mathrm{NaCI}$.

These results refer that bacteria play an important role to degradation TSS, and this point were economic important to reduced the amount of precipitation of chemical substances when added to waters founded in ponds as well as $\left(\mathrm{AI}_{2} \mathrm{SO}_{4}\right.$ ), and reduced the money and stress. These results were similar to the findings of [21] which showed to decreased of TSS by using bacteria. It means that the bacterial strains were able to degrade crude oil consists of saturated and aromatic hydrocarbons and asphaltic compounds of varying molecular weight, complexity, and degree of susceptibility to microbial oxidation[25].

Figure.6 showed that the reduction of TPH was increased by an increase in the reaction's duration and increased temperature, $\mathrm{pH}$ and $\mathrm{NaCI}$ concentration in wastewater treatment with mixed bacterial cultures during $48 \mathrm{~h}$, and the percentage removal of TPH reached to $99.98 \%$ when compared with control. This figure showed decreased concentration and appear many peaks when compared with control, and Fig.7 show containing foam in wastewater treatment with alone and mixed bacteria, these results refer to the ability of these bacteria to consumed hydrocarbons in wastewater .

In the same time the numbers of bacteria were increased to $5 \times 10^{8}$ after incubation $48 \mathrm{~h}$ in $40 \mathrm{c}^{\mathrm{o}} \mathrm{Table} .7$.

Table 7:Total numbers of isolated bacteria after treatment with wastewater.

\begin{tabular}{|c|c|c|c|c|}
\hline Isolated bacteria & Temperature $\left(\mathrm{C}^{\mathrm{o}}\right)$ & $\mathrm{pH}$ & Salt concentration $(\mathrm{gm})$ & Microbial Numbers \\
\hline P.aeruginosa & \multirow[t]{4}{*}{ - } & \multirow{4}{*}{2} & \multirow[t]{4}{*}{ (5) } & $2.0 \times 10^{8} *$ \\
\hline E.coli & & & & $1.0 \times 10^{8}$ \\
\hline Mixed & & & & $3.0 \times 10^{7}$ \\
\hline Control & & & & 0.0 \\
\hline P.aeruginosa & \multirow{4}{*}{20} & \multirow{4}{*}{4} & \multirow{4}{*}{0.5} & $2.0 \times 10^{7}$ \\
\hline E.coli & & & & $1.0 \times 10^{7}$ \\
\hline Mixed & & & & $4.0 \times 10^{7}$ \\
\hline Control & & & & 0.0 \\
\hline P.aeruginosa & \multirow{4}{*}{30} & \multirow{4}{*}{6} & \multirow{4}{*}{1.0} & $3.0 \times 10^{7}$ \\
\hline E.coli & & & & $3.0 \times 10^{8}$ \\
\hline Mixed & & & & $4.0 \times 10^{8}$ \\
\hline Control & & & & 0.0 \\
\hline P.aeruginosa & \multirow{4}{*}{40} & \multirow{4}{*}{8} & \multirow{4}{*}{2.0} & $4.0 \times 10^{7}$ \\
\hline E.coli & & & & $4.0 \times 10^{8}$ \\
\hline Mixed & & & & $5.0 \times 10^{8}$ \\
\hline Control & & & & 0.0 \\
\hline
\end{tabular}

* Non-significant 
A

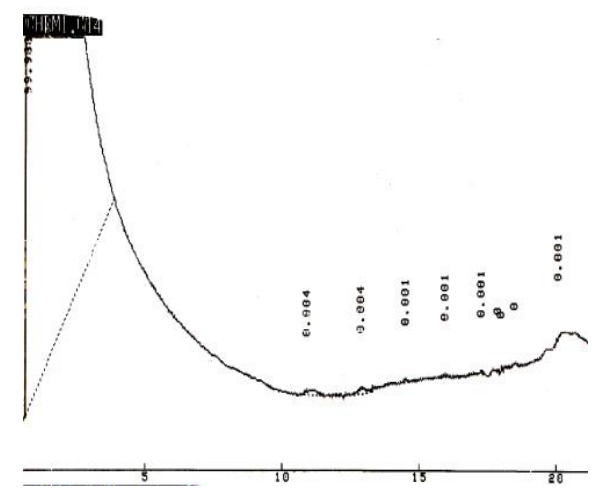

C

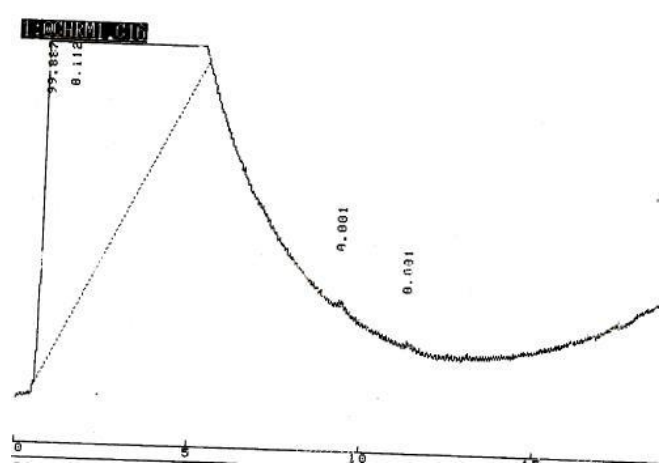

B

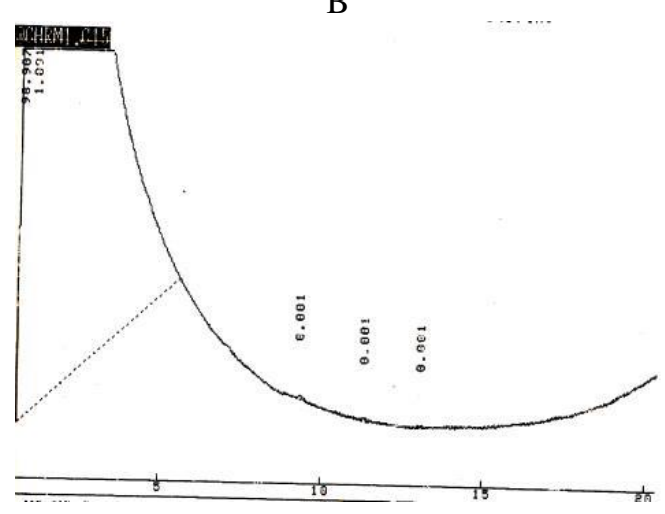

D

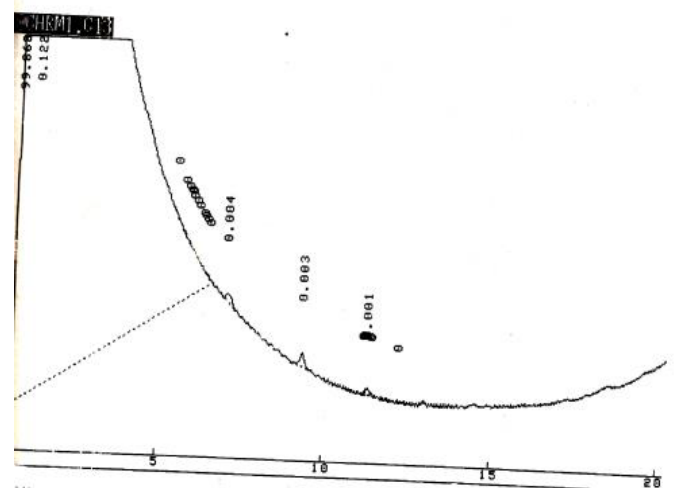

Fig. 6: GC Chromatogram of removal Total Petroleum Hydrocarbon (TPH) in wastewater treatment with (A: P.aeruginosa, B: E.coli, C: Mixed, D: Control) after $48 \mathrm{~h}$.

E .coli

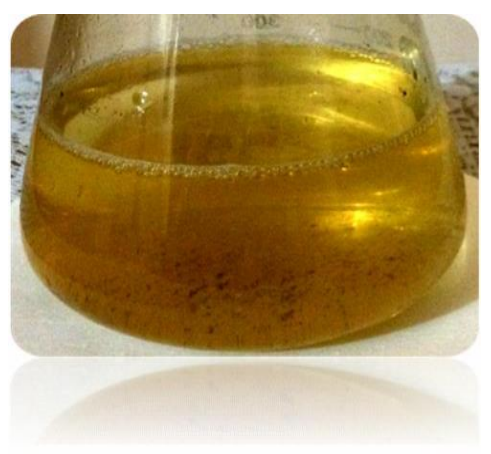

Mixed

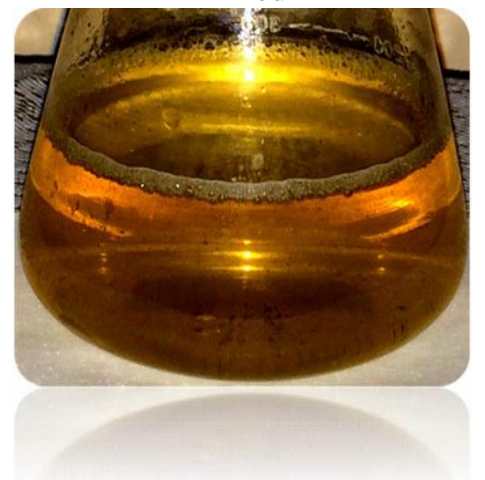

P.aeruginosa

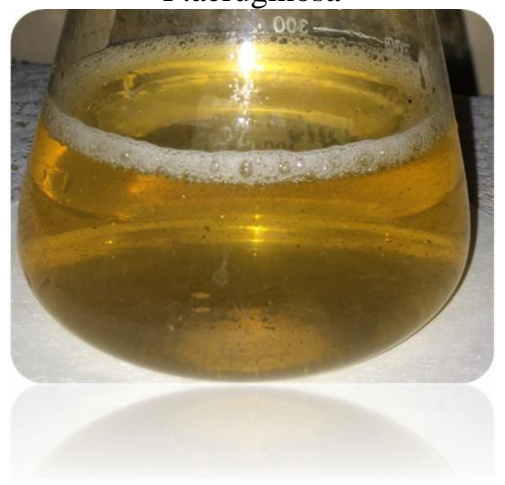

Control

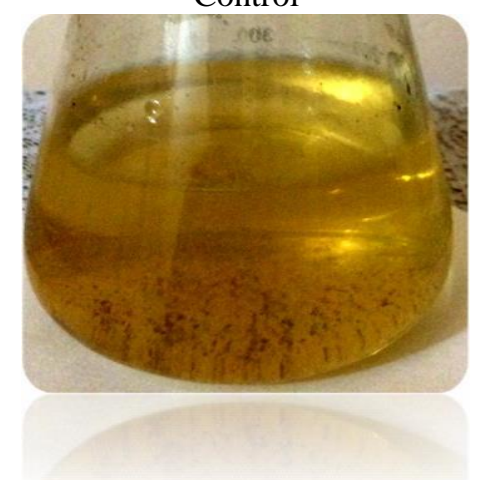

Fig. 7: Ability of isolated bacteria to biodegradation of Total Petroleum Hydrocarbon (TPH) in 40c $\mathrm{c}^{\circ}$ pH 8 and $2.0 \mathrm{gm} / \mathrm{I}$ NaCI. 
These results were similar to the findings of [24] which show that the TPH value was reached with $99.98 \%$ when compared with initial concentration of $770 \mathrm{mg} \mathrm{1-1.}$

Studies of [26] and [27] it is clear that very low salt concentrations reduce hydrocarbonoclastic activity and the optimum biodegradation results are reached whitin moderate salinity ranges.

First of all, it is necessary to consider that hydrocarbons are less bioavailable in hypersaline environments that in nonsaline ones [28].

\section{Conclusion}

The oil degrading bacteria isolated from the soil and wastewater in the present study included P.aeruginosa,E.coli , and the density of these bacteria were dominant than other bacteria. These bacteria were well adapted to degrade and utilize the Petroleum hydrocarbons. The mixed culture of these bacteria were beter than the axenic bacteria to removal of COD,TSS, and TPH.

The reduction of BOD,COD, TSS and TPH enhanced with increasing reaction's duration time, for given experimental conditions. The $\mathrm{pH}$ was effect on biodegradation of BOD,COD,TSS, and TPH reduction, also the highest reduction obtained at $\mathrm{pH} 8$.

The $2.0 \mathrm{gm} /$ I salt concentration (NaCI) achieved the highest efficiency in biodegradation of BOD,COD, TSS and TPH reduction. The temperature $40 \mathrm{c}^{\mathrm{o}}$, achieved the highest efficiency in biodegradation of COD, TSS and TPH.

Rehabilitation of oil contaminated soil and wastewater by the culture of mixed bacteria P.aeruginosa and E.coli were promising as it can reduce the oil pollution to acceptable levels for reuse of land and water within a short period.

\section{Acknowledgment}

The authors thank IBN SINA STATE Company, Minsitry of Industry and Minerals, Republic of IRAQ for helping us in instrumental supports.

\section{References}

[1] Hernandez A.,Mellado R.P., Martinez J .L, Metal accumulation and Vanadium induced multidrug resistance by environmental isolates of EscherchiahermaniiandEnterobactercloacae. Applied Environmental Microbiology, 64 (11), (1998), 4317 - 4320.

[2] Wake H., Oil refineries: a review of their ecological impacts on the aquatic environment. Estuarine Coast and Shelf Scince, 62(1-2), (2005), 131 -140. http://dx.doi.org/10.1016/j.ecss.2004.08.013.

[3] Burk S.L, Review of pollutants in petroleum refinery wastewater and effect upon aquatic organisms, International Journal of Environment, 7(4), (1982), 271 - 283. http://dx.doi.org/10.1016/0160-4120(82)90117-9.

[4] Otokunefor T.V.,Obiukwu C, Impact of refinery effluent on the physicochemical properties of a water body in the Niger delta. Applied Ecology and Environment Research, 3(1), (2005), 61 - 72. http://dx.doi.org/10.15666/aeer/0301_061072.

[5] Tisler T., Zagroc- KoncanJ., Ros M., Cotman M, Biodegradation and toxicity of wastewater from industry producing mineral fibres for thermal insulation ., Chemospher,38(6), (1999), 1347 - 1352. http://dx.doi.org/10.1016/S0045-6535(98)00536-0.

[6] Saha M.K. , Konar S.K, Chronic effects of petroleum refinery effluent on aquatic ecosystem , Environment Ecology, 2(3) ,(1985),17 - 20.

[7] Atlas R.M, Microbial degradation of petroleum hydrocarbons: an environmental perspective. Microbiology Review, 45(1), (1981), 180- 209.

[8] Davis J.S., Westlake D .W, Crude oil utilization by fungi. Candian Journal of Microbiology, 25 (2), (1979), 146 - 156. http://dx.doi.org/10.1139/m79-023.

[9] Cerniglia C.E., White G.L., Heflich R .H , Fungal metabolisms and detoxification of polycyclic aromatic hydrocarbon . Arch .Microbiology. , 50, (1985), 649 - 655.http://dx.doi.org/10.1007/bf00411031.

[10] Sutherlands J.B, Detoxification of polycyclic aromatic hydrocarbons by fungi. Industrial Microbiology, 9(1), (1999), 53 - 62.

[11] Boonchan S., Britz M.L., Stanley G.A, Degradation and minerlization molecular weight polycyclic aromatic hydrocarbons by defined fungalbacterial cocultures ., Applied Environmental Microbiology, 66(3),(2000), 1007- 1019. http://dx.doi.org/10.1128/AEM.66.3.1007-1019.2000.

[12] American Public Health Association- APHA. Standard methods for the examination of water and wastewater,20ed. Washinton:APHA, (1998),pp: 5-43.

[13] Holt J.G. ,Krieg N. R., Sneath P.H.A., Staley J., Williams S.T,Bergy's manual of determination bacteriology . $9^{\text {th }}$ ed. Editor by Williams and Wilkins. Baltimore,Maryland. (1994), pp: 787.

[14] Reddy K.R, Microbiology,Parasitology. Question Answer review. 4th edition, PARAS. Medical publisher, (2010), pp.: 58 - 189.

[15] Bergy's N.R., Holt J.G. Bergy's manual of systematic bacteriology, 9th edition, Williams and Wilkins Baltimore, (1994), pp: 756.

[16] Cappuccino J.G., Sherman N, Microbiology a laboratory manual; 2nd edition,California. The BenjaminsColumning publishing Company, (1987),pp: 283-289.

[17] Farid W.A,Bioremediation of oil contaminated oil by axenic and mixed cultures of bacteria and fungi . AI- Taqani Journal, 25(2), (2012), 1- 6.

[18] Minai - Tahrani, D., ShahriariM. H. ,Saveghebi - Firoozabadi G ., Kalantari F., Azizi M, Effect of light crude oil - contaminated soil on growth and germination of Festucaarundinaccea ., Applied Scince, 7(18),(2007), 2623 - 2628

[19] MargesinR. , Labbe D., Schinner F., Greer C.W. , Whyte L.G,Characterization of hydrocarbon degrading microbial populations in contaminated and Pristine alpine soil . Applied Environmental Microbiology, 69(8), (2003), 3085 - 3092. http://dx.doi.org/10.1128/AEM.69.6.3085-3092.2003.

[20] Atlas R.M., BarthaR. Microbial degradation of oil pollutant workshop state Union PubI .No. LSUSG - 73-01, (1972), $283-289$.

[21] Hussien A, A ., Hassan S , S , Efficiency of local isolates bacteria Psedomonas aeruginosa and Serratiaficariain petroleum wastewater treatment .Iraqi , Biotecnology Journal,. 7(1), (2008), 96 - 109.

[22] Nwachukwu S.U., UgojiE.O,Impact of crude petroleum spills on microbial communities of tropical soils . International Journal of Environment. Scince, 21(1), (1995), $169-175$. 
[23] Belkin S., Brenner A., Abeliovich A, Biological treatment of high salinity chemical industrial wastewater. Water Science Technology,(1993), 27,(1993), $105-112$.

[24] Najafi M., Kashi G, Removal of poly aromatic hydrocarbons and total petroleum hydrocarbon by using bio - enzyme: a batch study, Medicine and Bioenginering, 1(1), (2012), 42 -47. http://dx.doi.org/10.12720/jomb.1.1.42-47.

[25] Raymond R.L., Davis J.B, Alkane utilization and lipid formation by Anocardia. Applied Microbiology, 8(6), (1960), 329 -334

[26] Abed R.M. , AI-Thukair A., DeBeer D, Bacterial diversity of a cyanobacterial mat degrading petroleum compounds at elevated salinities and temperatures ., FEMS . Microbiology Ecology Journal, 57(2), (2006), 290 - 301. http://dx.doi.org/10.1111/j.1574-6941.2006.00113.x.

[27] Diaz M .P. , Boyd K.G. , Grigson S.G.W., Burgess J.G, Biodegradation of crude oil across a wide range of salinities by an extremely halotolerant bacterial consortium MPD-M , immobilized onto polypropylene fibers , Biotechnology Bioenginering, 79 (2) ,(2002), 145 - 153. http://dx.doi.org/10.1002/bit.10318.

[28] Luiz F .M. , Raquel S.P ,Biodegradation Petroleum hydrocarbons in hypersaline environments., Brazilian Journal Microbiology ,43 (3 ) ,(2012),865-872.http://dx.doi.org/10.1590/S1517-83822012000300003. 